\title{
CHEMISTRY OF PYRROLIZINES; REACTIONS WITH CYANOGEN BROMIDE AND TRIFLUOROACETIC ANHYDRIDE
}

\author{
W. VERBOOM, G. W. VISSER and D. N. REINHOUDT* \\ Laboratory of Organic Chemistry, Twente University of Technology, Enschede, The Netherlands
}

(Received in U.K. 16 November 1981)

\begin{abstract}
Interaction of the pyrrolizine 3 with cyanogen bromide in a tetrahydrofuran/water mixture affords addition to the enamine double bond with formation of 5 which can be aromatized to 6 by silica gel. Reaction of 6 with cyanogen bromide in the same solvent mixture yields the indoline $8 \mathrm{a}$ which structure is proved in a chemical way by conversion of the product into the aldehyde $8 \mathrm{~d}$. The different reaction pathway is discussed in terms of steric hindrance by the ester groups. Treatment of 6 with trifluoroacetic anhydride gives the trifluoroacetylated compound 11. Removal of the sterically hindered ester groups in 6, with acetic acid in quinoline at $200^{\circ}$, is accompanied by the simultaneous decarboxylation to yield the pyrrolo[1,2-a]indole 13 .
\end{abstract}

Recently we reported that the reactions of 3-(1-pyrrolidinyl) thiophenes ${ }^{1}$ and 1 -pyrrolidinyl cycloalkenes ${ }^{2,3}$ with dimethyl acetylenedicarboxylate in polar solvents give pyrrolizines instead of the cyclobutene derivatives that are formed in apolar solvents. Since the $1 \mathrm{H}$ pyrrolo[1,2-a]indole system is the chemical backbone of the anti-tumor antibiotic mitomycin 2 we are currently exploring the possibility of modification of our pyrrolizines and the conversion of these into analogues of mitomycins. Since the structures of the mitomycins were first elucidated, ${ }^{4}$ several approaches to their synthesis have been reported ${ }^{5}$ and a total synthesis was accomplished via compound 1 by Kishi et al. ${ }^{6}$ However, the number of steps and the low overall yield renders the synthesis of a large number of derivatives very difficult.<smiles></smiles>

1<smiles>[X]C1=C(C)C(=O)C2=C(C1=O)[C@@H](COC(N)=O)[C@@]1(OC)[C@H]3[C@@H](CN2[R])N31</smiles>

$\underset{\sim}{2}$

The experiments described in this paper have been carried out with the readily accessible $5,7,7 \mathrm{a}, 8,9$, 10-hexahydro-7-methoxycarbonyl- $6 \mathrm{H}$-benzo[g]pyrrolo[1, 2-a]indole-7-acetic acid methyl ester $\left(3, \mathrm{E}=\mathrm{COOCH}_{3}\right)$ as a model system. Our first objective was to study the conversion of the pyrrolizine system into an azocine 4 via reaction with cyanogen bromide or trifluoroacetic anhydride in a similar way to that described by Kametani et $a l^{7}$ In azocine $4 \mathrm{R}^{2}$ must be converted in several steps<smiles>FCC1(CF)C2=C(c3ccccc3CC2)N2CCCC21</smiles>

3

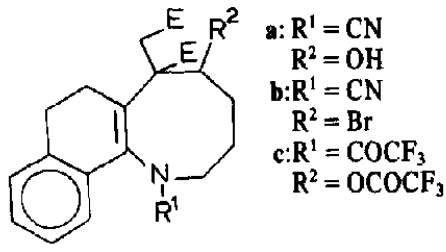

4

into a keto function which can serve 1) to introduce a handle for the aziridine group, 2) to remove one of the ester groups and 3), via the acetal, for the introduction of the methoxy group. Surprisingly, we found a mode of reaction which is different from known reactions of pyrrolizines with both cyanogen bromide and trifluoroacetic anhydride.

\section{RESULTS AND DISCUSSION}

Reactions with cyanogen bromide. Reactions of tertiary amines with cyanogen bromide (the von Braun reaction) are normally carried out in inert solvents such as diethyl ether, chloroform or benzene. ${ }^{8}$ Albright et al., ${ }^{9}$ however, used mixtures of tetrahydrofuran and water or alcohols and Rönsch ${ }^{10}$ carried out the reaction in the presence of magnesium oxide. Using these conditions they were able to introduce directly a hydroxy- or an alkoxy group instead of a bromine atom.

The pyrrolizine 3 was reacted with cyanogen bromide in a mixture of tetrahydrofuran and water $(25: 10)$ at room temperature to give a product which was not the 
expected azocine $4 a$ in $89 \%$ yield. According to the mass spectrum and elemental analysis the elemental composition of the reaction product was $\mathrm{C}_{21} \mathrm{H}_{23} \mathrm{BrN}_{2} \mathrm{O}_{4}$ indicating that a bromine and not an $\mathrm{OH}$ group was incorporated. In the ${ }^{1} \mathrm{H}$ NMR spectrum the characteristic N-Ć H-signal for pyrrolizines at $\delta 4.60 \mathrm{ppm}$ (dd, $J=5.5$ and $11 \mathrm{~Hz}$ ) was still present and the ${ }^{13} \mathrm{C}$ NMR spectrum showed that the absorptions of the original double bond were replaced by $-\stackrel{C}{C}-\mathrm{Br}$ and $-\stackrel{C}{C}-\mathrm{CN}$ signals at $\delta 73.0$ and $72.1 \mathrm{ppm}$. On the basis of these data we concluded that the reaction product was 6a-bromo-7-carboxy-11a-cyano$5,6 \mathrm{a}, 7,7 \mathrm{a}, 8,9,10,11 \mathrm{a}-$ octahydro-6 $\mathrm{H}$-benzo[g]pyrrolo[1,2-a] indole-7-acetic acid, dimethyl ester 5. Obviously addition of cyanogen bromide had taken place at the more reactive enamine double bond.

Due to the polarization of cyanogen bromide we would expect that the bromine attacks at the $\beta$-enamine carbon atom having the highest electron density.

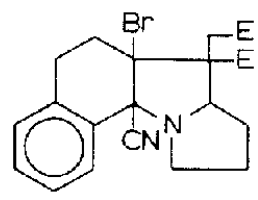

5

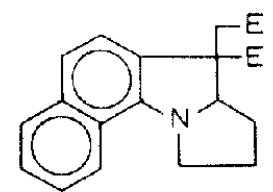

6
Reaction of compound 5 in the presence of silica gel gave rise to the formation of 7-carboxy-7a,8,9,10tetrahydro $-7 \mathrm{H}$ - benzo $[\mathrm{g}]$ pyrrolo[1,2 - $a]$ indole -7 - acetic acid, dimethyl ester 6 which could be crystallized from the crude reaction mixture in $30-40 \%$ yield.

Direct aromatization of pyrrolizine 3 with diisopentyldisulfide ${ }^{12}$ or $\mathrm{N}$-bromosuccinimide gave, according to the ${ }^{1} \mathrm{H}$ NMR spectra of the crude reaction mixtures, higher yields of pyrrolizine 6. However it was difficult to isolate pure 6 . In the case of the reaction with $N$ bromosuccinimide the pyrrolizine 6 could not be separated by chromatography from a product which contains a bromine atom in the aromatic ring.

Because pyrrolizine 6 does not possess the reactive enamine double bond of $\mathbf{5}$ and is therefore more closely related to the dioxoindole skeleton of mitomycin $C$ we have carried out further reactions with 6 . Reaction of pyrrolizine 6 with cyanogen bromide in tetrahydrofuranwater $(25: 10)$ at $40^{\circ}$ gave a $1: 1$ reaction product in $72 \%$

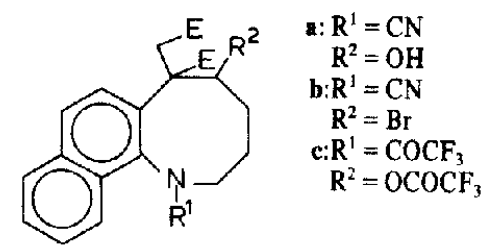

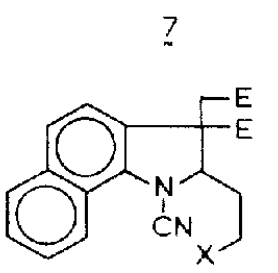

$\mathrm{X}=\mathrm{a}: \mathrm{CH}_{2} \mathrm{Br}$ b: $\mathrm{CH}_{2} \mathrm{OC}(\mathrm{O}) \mathrm{CH}_{3}$ c: $\mathrm{CH}_{2} \mathrm{OH}$ d: $\mathrm{CHO}$$$
8
$$

†For other examples of his type of reaction see Ref. 11. yield as was shown by mass spectrometry $\left(\mathrm{M}^{+} 444.072\right.$, calcd for $\mathrm{C}_{21} \mathrm{H}_{21} \mathrm{BrN}_{2} \mathrm{O}_{4} 444.069$ ) and the elemental analysis. The ${ }^{1} \mathrm{H}$ NMR spectrum showed the characteristic N-CH- signal at $\delta 5.07 \mathrm{ppm}$ (dd, $J=5.5$ and $8 \mathrm{~Hz})$ indicating that the $\mathrm{C}(7 \mathrm{a})-\mathrm{N}$ bond had not reacted, however a definite structure assignment could not be made. Assuming that there were two possibilities viz. 1) reaction of cyanogen bromide with the $\mathrm{N}-\mathrm{CH}$-bond and 2) reaction with the $\mathrm{N}-\mathrm{CH}_{2}-$ bond, we decided to replace the bromine atom by a hydroxyl function which after oxidation is converted into either a keto- or an aldehyde group. This would prove either one of the two possible structures (7a or 8a) in a chemical way. Attempts to substitute the bromine atom for a hydroxyl group with silver(l) oxide in an acetone-water mixture failed. The result was a very complicated reaction mixture in which no product could be identified. However, reaction with potassium acetate in the presence of 18-crown-6 in acetonitrile at reflux temperature according to Liotta et al. ${ }^{13}$ resulted in the formation of the corresponding acetate $\mathbf{8 b}$ in $86 \%$ yield. This compound could be smoothly converted into the alcohol $8 \mathrm{c}$ with sodium carbonate in $72 \%$ yield. Oxidation with pyridinium chlorochromate $^{14}$ in dichloromethane, ultimately leads to the formation of 3 - carboxy - 1 - cyano - 2 - (2 - formylethyl)benz [8]indoline-3-acetic acid, dimethyl ester $8 d$ in $80 \%$ yield. The structure of $\mathbf{8 d}$ was proven by its spectral data. Conclusive evidence for the aldehyde structure are the absorptions in the ${ }^{1} \mathrm{H}$ NMR spectrum at $\delta 9.87 \mathrm{ppm}$ and in the ${ }^{13} \mathrm{C}$ NMR spectrum at $\delta 199.5 \mathrm{ppm}$. From this result we concluded that in the pyrrolizine 6 cyanogen bromide had reacted with the $\mathrm{N}-\mathrm{CH}_{2}-$ bond with formation of $\mathbf{8 a}$. In the spectra of the crude reaction mixtures we could not demonstrate the presence of the azocine $\mathbf{7 b}$.

In their work Kametani et al. ${ }^{\gamma}$ reacted a compound that resembles our pyrrolizine namely 5,8 -diacetoxy-2, 3 , 9,9a-tetrahydro-7-methoxy-6-methyl- $1 H$-pyrrolo[1,2-a] indole 9 with cyanogen bromide and they observed that the von Braun reaction of 9 gave 7,10 -diacetoxy-5bromo - 1 - cyano - 1,2,3,4,5,6 - hexahydro - 8 - methoxy - 9 . methyl-1-benzazocine $10 \mathrm{a}$ in $56 \%$ yield, consequently reaction with the $\mathrm{N}-\stackrel{\text { I }}{\mathrm{H}}$-bond. They did not mention the presence of compounds originating by reaction with the $\mathrm{N}-\mathrm{CH}_{2}$-bond.<smiles>COc1c(C)c(OC(C)=O)c2c(c1OC(C)=O)CC1CCCN21</smiles>

$\stackrel{9}{\sim}$<smiles>[R]C1CCCN([R])c2c(c(OC(C)=O)c(C)c(OC)c2OC)C1</smiles>

$$
\text { a: } \begin{aligned}
\mathbf{R}^{1} & =\mathrm{CN} \\
\mathbf{R}^{2} & =\mathrm{Br} \\
\mathbf{b}: \mathbf{R}^{\mathbf{1}} & =\mathrm{COCF}_{3} \\
\mathbf{R}^{2} & =\mathrm{OCOCF}_{3}
\end{aligned}
$$

Reactions with trifluoroacetic anhydride. As an alternative way to convert pyrrolizines into azocines 
Kametani et al. ${ }^{7}$ found that the pyrrolo[1, 2-a]indole 9 reacted with trifluoroacetic anhydride in a sealed tube at $150^{\circ}$ to yield 7,10 - diacetoxy - 1,2,3,4,5,6 - hexahydro - 8methoxy-9-methyl-5-triffuoroacetoxy-1-trifluoroacetyl-1benzazocine 10 $\mathrm{m}$. Under the same conditions the pyrrolizines 3 and 6 reacted with trifluoroacetic anhydride to give complicated reaction mixtures from which no pure compound could be isolated. However, the reaction of pyrrolizine 3 with trifluoroacetic anhydride at reflux temperature $\left(40^{\circ}\right)$ is fast yielding a salt which was isolated. The mass spectrum showed a parent peak at $m / e 341$ (starting pyrrolizine 3 ) and in addition fragments originating from triffuoroacetic anhydride. Treatment of the salt with sodium bicarbonate in water gave the starting pyrrolizine 3 .

Pyrrolizine 6 reacted with trifluoroacetic anhydride at room temperature to give 7 - carboxy - 7a,8,9,10 - tetrahydro - 4 - (trifluoroacetyl) - $7 \mathrm{H}$ - benzo[g]pyrrolo[1,2- $a$ ] indole-7-acetic acid, dimethyl ester 11 which was isolated in $78 \%$ yield. The structure of 11 was proven by spectrascopic methods. The mass spectrum and elemental analysis showed that only a $\mathrm{CF}_{3} \mathrm{CO}$-group had been introduced. Besides, in the ${ }^{1} \mathrm{H}$ NMR spectrum the characteristic N-CH-absorption at $\delta 5.10 \mathrm{ppm}$ (dd, $J=5$ and $12 \mathrm{~Hz}$ ) is still present. On the basis of these data the azocine structure $7 \mathrm{c}$ could be excluded. Comparison of the 'H NMR spectra of the product and of pyrrolizine 6 showed essential differences in the aromatic patterns; the spectrum of the reaction product exhibited only five aromatic hydrogen atoms. Therefore we concluded that an electrophilic aromatic substitution had taken place. One of the aromatic hydrogens in the ${ }^{1} \mathrm{H}$ NMR spectrum is shifted downfield to $89.26 \mathrm{ppm}$ (dd) (influence of the nearest $\mathrm{CF}_{3} \mathrm{CO}$-group) and showed a $J_{\text {ortho }}$ of $8 \mathrm{~Hz}$ and $J_{\text {meta }}$ of $1.5 \mathrm{~Hz}$ so that the only possibility is that the $\mathrm{CF}_{3} \mathrm{CO}$-group had been introduced at the $\mathrm{C}(4)$ position.

In the literature it has been reported that trifluoroacetic anhydride is capable of effecting trifluoroacetylation in reactive aromatic and heterocyclic nuclei. ${ }^{15}$ In the case of Kametani et al. ${ }^{7}$ triffuoroacetylation is not possible because in pyrrolo[1, 2-a]indole 9 all aromatic positions are blocked.

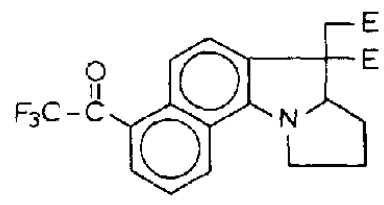

11

We concluded that we were not able to convert the pyrrolizine 6 into the azocines 7 either with cyanogen bromide or with trifluoroacetic anhydride. A reason that in pyrrolizine 6 cyanogen bromide does not react with the annulating $\mathrm{N}-\mathrm{CH}$-bond might be the presence of the bulky ester groups which possibly prevent an attack at the $\mathrm{C}(7 \mathrm{a})$ position. Therefore we have subsequently tried to remove these ester groups first.

Removal of the ester groups. With classical methods such as sodium hydroxide or hydrogen chloride in water or dioxane, concentrated sulphuric acid or trifluoroacetic acid we were not able to remove the ester groups.
Fétizon et al. ${ }^{16}$ reported acetic acid in quinoline to be an effective method for the hydrolysis of hindered esters. Reaction of pyrrolizine 6 with this reagent at $200^{\circ}$ afforded not the expected diacid 12 but 9,10-dihydro7 - methyl - $8 \mathrm{H}$ - benzo[g]pyrrolo[1,2 - a] indole 13 in $36 \%$ yield. The structure of 13 was proven by spectroscopic methods. For instance

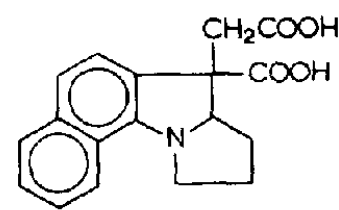

12

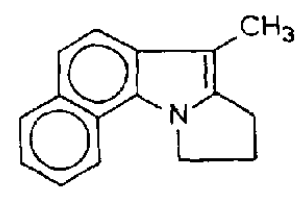

13 the 'H NMR spectrum showed the presence of a methyl group at $\delta 2.32 \mathrm{ppm}$ and an $\mathrm{N}-\mathrm{CH}_{2}$-group at $\delta 4.50 \mathrm{ppm}$ (t, $J=7 \mathrm{~Hz}$ ); signals of methoxy- or acid groups were absent. The ' $\mathrm{H}$ NMR spectrum resembled that of the known 2, 3-dihydro-9-methyl-1 $H$-pyrrolo[1, 2-a]indole. ${ }^{17}$

We assume that the formation of 13 occurs via the intermediate diacid 12 which eliminates two moles of carbon dioxide. This was proven by heating the diacid $\mathbf{1 2}$ in quinoline at $200^{\circ}$ which also resulted in formation of 13. This diacid 12 could be prepared by reaction of the pyrrolizine 6 with potassium tert-butoxide in dimethylsulfoxide according to Bartlett et al. ${ }^{18}$ Because this diacid is very soluble in water and difficult to separate from salts, attempts to isolate the diacid in a pure state failed. However, the 'H NMR spectrum clearly revealed the absence of the ester groups. The IR- and mass spectrum further supported this structural assignment.

To our knowledge this conversion of 3 via 6 into 13 represents the first synthesis of derivatives of the 9 , 10-dihydro-8H-benzo[g]pyrrolo[1, 2-a]indole system.

\section{EXPERIMENTAL}

M.ps were determined with a Reichert meiting point apparatus and are uncorrected. ${ }^{1} \mathrm{H}$ and ${ }^{13} \mathrm{C}$ NMR spectra were recorded with a Bruker WP80-FT and a Varian XL-100 spectrometer, respectively, in $\mathrm{CDCl}_{3}$ with TMS as internal standard. Mass spectra were obtained with a Varian Mat 311A spectrometer and IR spectra with a Perkin-Elmer 257 spectrophotometer. Elemental analyses were carried out by the Element Analytical section of the Institute for Organic Chemistry TNO, Utrecht, The Netherlands, under the supervision of Mr. W. J. Buis. Pyrrolizine 3 was prepared as described. ${ }^{3}$

6a-Bromo-7-carboxy-11a-cyano-5, 6a, 7, 7a, 8, 9, 10, 11a-octahydro-6H-benzo[g]pyrrolo $[1,2-\mathrm{a}]$ indole-7-acetic acid, dimethyl ester 5

To a soln of $3(17.1 \mathrm{~g}, 0.05 \mathrm{~mol})$ in $400 \mathrm{ml} \mathrm{THF} / \mathrm{H}_{2} \mathrm{O}(25: 10)$ were added magnesium oxide $(4.0 \mathrm{~g}, 0.1 \mathrm{~mol})$ and, dropwise, a soln. of cyanogen bromide $(10.6 \mathrm{~g}, 0.1 \mathrm{~mol})$ in $100 \mathrm{mI} \mathrm{THF} / \mathrm{H}_{2} \mathrm{O}$ $(25: 10)$ at room temp. After stirring for $1 \mathrm{~h}$ the magnesium oxide was filtered off and the filtrate concentrated in vacuo to about $1 / 10$ of the original volume. The crude 3 crystallized from the filtrate. 5 was collected on a sintered glass filter, successively washed twice with $\mathrm{MeOH}$ and $\mathrm{Et}_{2} \mathrm{O}$ and dried over $\mathrm{CaCl}_{2}$ (yield $89 \%$ ). 5 could be used without further purification for the preparation of 6 . A sample of 5 was recrystallized from MeOH. M.p. $133-133.5^{\circ} ;{ }^{1} \mathrm{H}$ NMR: $87.6-7.1(\mathrm{~m}, 4 \mathrm{H}, \mathrm{Ar}), \delta 4.60(\mathrm{dd}, J=5.5$ and $11 \mathrm{~Hz}, \mathrm{~N}-\stackrel{b}{\mathrm{C}} \mathrm{H}-), \delta 3.81$ and $3.68\left(\mathrm{~s}, \mathrm{OCH}_{3}\right), \delta 3.7-1.4(\mathrm{~m}, 12 \mathrm{H}$, $\mathrm{CH}_{2} \mathrm{E}, \mathrm{N}-\mathrm{CH}_{2}-,-\mathrm{CH}_{2}-{ }^{13} \mathrm{C}$ NMR: $\delta 171.6$ and $170.6(\mathrm{~s}, \mathrm{C}=0)$, 8132.2 (s), 131.0 (s), 129.2 (d), 128.9 (d), 128.3 (d) and 126.6 (d) (Ar), $\delta 120.0(\mathrm{~s}, \mathrm{C} \equiv \mathrm{N}), \delta 73.0$ and $72.1\left(\mathrm{~s},-\mathrm{C}_{-}-\mathrm{Br}\right.$ and $\left.-\mathrm{C}_{\mathrm{C}}-\mathrm{C} \equiv \mathrm{N}\right)$, 
866.1 (d, N-CH-), $858.3\left[\mathrm{~s}, \mathrm{C}\left(\mathrm{E}\left(\mathrm{CH}_{2} \mathrm{E}\right], 852.6\right.\right.$ and $51.9\left(\mathrm{q}, \mathrm{OCH}_{3}\right)$ $\delta 48.8\left(\mathrm{t}, \mathrm{N}-\mathrm{CH}_{2}-\right), \delta 40.6\left(\mathrm{t}, \mathrm{CH}_{2} \mathrm{E}-\right), \delta 32.2,28.4,28.1$ and $27.3(\mathrm{t}$, $-\mathrm{CH}_{2}-$ ). IR (KBr): $1742 \mathrm{~cm}^{-1}(\mathrm{C}=0)$. MS: $\mathrm{M}^{+} 446.087$, Calc. 446.084, (Found: C, 56.20, H, 5.21; N, 6.10. Calc. for $\left.\mathrm{C}_{21} \mathrm{H}_{23} \mathrm{BrN}_{2} \mathrm{O}_{4}(447.33): \mathrm{C}, 56.41 ; \mathrm{H}, 5.15 ; \mathrm{N}, 6.26 \%\right)$.

7-Carboxy-7a,8,9,10-tetrahydro-7H-benzo[g]pyrrolo[1,2-a]indole7-acetic acid, dimethyl ester 6

Silica gel $(60 \mathrm{~g})$ was added to a soln of $5(6.0 \mathrm{~g}, 13 \mathrm{mmol})$ in $150 \mathrm{ml} \mathrm{CHCl}$. The resulting slurry was stirred for $20-24 \mathrm{~h}$ at room temp. The silica gel was filtered off on a sintered glass filter and washed five times with EtOAc. The filtrate was dried with $\mathrm{MgSO}_{4}$ and subsequently concentrated in vacuo. The resulting oil solidified upon the addition of a small amount of $\mathrm{MeOH}$. Purification by trituration with $\mathrm{MeOH}$ afforded the pure 6 in $30-40 \%$ yield. M.p. 148-150 ; ${ }^{1} \mathrm{H}$ NMR: $88.2-7.95(\mathrm{~m}, 1 \mathrm{H}, \mathrm{Ar})$, 87.9-7.7 (m, 1H, Ar), 87.5-7.2 (m, 4H, Ar), 84.94 (dd, $J=5$ and $11 \mathrm{~Hz}, \mathrm{~N}-\mathrm{CH}-), 83.74$ and $3.68\left(\mathrm{~s}, \mathrm{OCH}_{3}\right), \delta 3.76$ and $2.84(\mathrm{AB}-\mathrm{q}$, $\left.J=18 \mathrm{~Hz}, \mathrm{CH}_{2} \mathrm{E}\right), 82.3-1.2\left(\mathrm{~m}, 4 \mathrm{H},-\mathrm{CH}_{2}-\right)$. ${ }^{1} \mathrm{C}$ NMR 8174.0 and 171.9 (s, C=0), 8149.9 (s), 135.3 (s), 128.3 (d), 125.7 (d), 125.2 (s), 124.3 (d), 123.9 (d), 122.5 (s), 121.3 (d) and 120.2 (d) (Ar), $872.3(\mathrm{~d}$, $\mathrm{N}-\mathrm{CH}-), 854.5$ [s, $\left.\mathrm{C}(\mathrm{E}) \mathrm{CH}_{2} \mathrm{E}\right], 853.9,52.7$ and $51.9\left(\mathrm{OCH}_{3}\right.$ and $\left.\mathrm{N}-\mathrm{CH}_{2}-\right), \delta 39.1$ (t, $\left.\mathrm{CH}_{2} \mathrm{E}\right), 827.0$ and $26.4\left(\mathrm{t},-\mathrm{CH}_{2}-\right)$. IR (KBr): $1721 \mathrm{~cm}^{-1}(\mathrm{C}=0)$. MS: $\mathrm{M}^{+}$339.148, Calc. 339.147. (Found: $\mathrm{C}$, 70.53; $\mathrm{H}, 6.31 ; \mathrm{N}, 4.01$. Calc. for $\mathrm{C}_{20} \mathrm{H}_{21} \mathrm{NO}_{4}$ (339.395): C, 70.78; $\mathrm{H}, 6.24 ; \mathrm{N}, 4.13 \%$ )

2-(3-Bromopropyl)-3-carboxy-1-cyanobenz[g]indoline - 3 - acetic acid, dimethyl ester $8 a$

To a soln of $6(1.0 \mathrm{~g}, 2.9 \mathrm{mmol})$ in $100 \mathrm{ml} \mathrm{THF} / \mathrm{H}_{2} \mathrm{O}(25: 10)$ was added magnesium oxide $(0.4 \mathrm{~g}, 10 \mathrm{mmol})$ and cyanogen bromide $(2.0 \mathrm{~g}, 19 \mathrm{mmol})$ at room temp. The reaction mixture was heated at $40^{\circ}$ for $24 \mathrm{~h}$. After filtration of the magnesium oxide, $100 \mathrm{ml} \mathrm{H} \mathrm{H}_{2} \mathrm{O}$ was added. The product was isolated by extraction (3-4 times) with $\mathrm{CHCl}_{3}$. The combined extracts were washed with a saturated $\mathrm{NH}_{4} \mathrm{Cl}$ solution, dried with $\mathrm{MgSO}_{4}$ and then concentrated in vacuo. The resulting oil solidified upon the addition of a few drops of $\mathrm{MeOH}$. Purification by trituration with $\mathrm{MeOH}$ gave pure $8 \mathrm{a}$ in $75 \%$ yield. M.p. $133-134^{\circ}$; ${ }^{1} \mathrm{H}$ NMR: $\delta 8.5-8.3(\mathrm{~m}, 1 \mathrm{H}, \mathrm{Ar}), 87.9-7.3(\mathrm{~m}, 5 \mathrm{H}, \mathrm{Ar}), 85.07(\mathrm{dd}, J=5.5$ and

$8 \mathrm{~Hz}, \mathrm{~N}-\stackrel{!}{\mathrm{C}} \mathrm{H}-), 83.75$ and $3.73\left(\mathrm{~s}, \mathrm{OCH}_{3}\right), 83.6-3.4(\mathrm{~m}, 2 \mathrm{H}$, $\mathrm{CH}_{2} \mathrm{Br}$ ), 82.82 (part of AB-q, $\left.J=18 \mathrm{~Hz}, \mathrm{CH}_{2} \mathrm{E}\right), 82.4-2.0(\mathrm{~m}, 2 \mathrm{H}$ $\left.-\mathrm{CH}_{2-}\right), 82.0-1.6\left(\mathrm{~m}, 2 \mathrm{H},-\mathrm{CH}_{2-}\right)$. ${ }^{3} \mathrm{C}$ NMR: $\delta 171.8$ and $171.0(\mathrm{~s}$, $\mathrm{C}=0$ ), 8135.5 (s), 134.7 (s), 128.6 (d), 127.0 (d), 126.0 (d), 125.2 (s), $122.0(\mathrm{~s}), 121.2$ (d) and 120.6 (d) (Ar), $8113.9(\mathrm{~s}, \mathrm{C} \equiv \mathrm{N}), 870.3$ (d, N-c $\mathrm{CH}-$ ), $856.9\left[\mathrm{~s}, \mathrm{C}(\mathrm{E}) \mathrm{CH}_{2} \mathrm{E}\right], \delta 53.3$ and $52.4\left(\mathrm{q}, \mathrm{OCH}_{3}\right.$ ), $836.3\left(\mathrm{t}, \mathrm{CH}_{2} \mathrm{E}\right), 832.8$ and $29.0\left(\mathrm{t},-\mathrm{CH}_{2} \mathrm{Br}\right.$ and $\left.-\mathrm{CH}_{2-}\right)$. IR $(\mathrm{KBr})$ : $2218 \mathrm{~cm}^{-1}(\mathrm{C} \equiv \mathrm{N}), 1735$ (sh) and $1726 \mathrm{~cm}^{-1}(\mathrm{C}=0)$. MS: $\mathrm{M}^{+}$ 444.072, Calc. 444.069. (Found: C, 56.63; H, 4.78; N, 6.32. Calc. for $\mathrm{C}_{21} \mathrm{H}_{21} \mathrm{BrN}_{2} \mathrm{O}_{4}$ (445.32): $\mathrm{C}, 56.64 ; \mathrm{H}, 4.75 ; \mathrm{N}, 6.29 \%$ ).

3-Caboxy-1-cyano-2-(3-hydroxypropy/)benz[g]indoline-3-acetic acid, dimethyl ester, acetate (ester) $8 b$

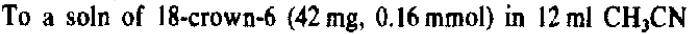
was added dry potassium acetate $(0.3 \mathrm{~g}, 3 \mathrm{mmol})$ under $\mathrm{N}_{2}$ at room temp. After stirring for $30 \mathrm{~min}, 8 \mathrm{a}(0.60 \mathrm{~g}, 1.3 \mathrm{mmol})$ was added. The resulting mixture was refluxed for $3.5 \mathrm{~h}$. After cooling to room temp. $50 \mathrm{ml} \mathrm{CHCl} 3$ was added. The organic layer was washed with water, dried with $\mathrm{MgSO}_{4}$ and passed through a short path of silica gel in order to remove the 18-crown-6. After removal of the solvent in vacuo the resulting oil solidified upon the addition of a few drops of $\mathrm{MeOH}$. Purification by trituration with diisopropyl ether and recrystallization from $\mathrm{CHCl}_{3} /$ ight petroleum (60/80) afforded pure $8 \mathrm{~b}$ in $86 \%$ yield. M.p. $119-120.5^{\circ}$; H NMR: $88.5-8.3(\mathrm{~m}, 1 \mathrm{H}, \mathrm{Ar}), 88.0-7.25$ (m, 5H, Ar), 85.06 (dd, $J=6$ and $8 \mathrm{~Hz}, \mathrm{~N}-\mathrm{CH}-), 84.25-4.0\left(\mathrm{~m}, 2 \mathrm{H}, \mathrm{CH}_{2}-\mathrm{OAc}\right), 83.74$ (s, $\left.6 \mathrm{H}, \mathrm{OCH}_{3}\right), 83.59$ and $2.80\left(\mathrm{AB}-\mathrm{q}, J=18 \mathrm{~Hz}, \mathrm{CH}_{2} \mathrm{E}\right), \delta 2.03(\mathrm{~s}$, $3 \mathrm{H}, \mathrm{H}_{3} \mathrm{C}-\stackrel{\mathrm{C}}{\mathrm{C}}=0$ ), $82.2-1.5\left(\mathrm{~m}, 4 \mathrm{H},-\mathrm{CH}_{2}-\right) .{ }^{13} \mathrm{C}$ NMR: $\delta 171.8$,

tThe other part is hidden under the $\mathrm{OCH}_{3}-$ and $\mathrm{CH}_{2} \mathrm{Br}-$ signals.
171.1 and 170.7 (s, $C=0$ ), $8135.6(\mathrm{~s}), 134.7$ (s), 128.6 (d), 127.0 (d), 125.9 (d), 125.3 (s), 122.0 (s), 121.2 (d) and 120.7 (d) (Ar), $\delta 113.9(\mathrm{~s}, \mathrm{C}=\mathrm{N}), 870.7(\mathrm{~d}, \mathrm{~N}-\mathrm{CH}-), 863.5\left(\mathrm{t}, \mathrm{CH}_{2}-\mathrm{OAc}\right), 856.9$ [s, C(E)CH $\mathrm{CH}_{2} \mathrm{E}$ ], 853.3 and $52.3\left(\mathrm{q}, \mathrm{OCH}_{3}\right), 836.2\left(\mathrm{t}, \mathrm{CH}_{2} \mathrm{E}\right), 827.1$ and $25.4\left(\mathrm{t},-\mathrm{CH}_{2}\right), \delta 22.7\left(\mathrm{q}, \mathrm{H}_{3} \mathrm{C}-\mathrm{C}=0\right.$ ). IR (KBr): $2220 \mathrm{~cm}^{-1}$ $(C \equiv N), \quad 1734 \mathrm{~cm}^{-1} \quad(C=0)$. MS: $M^{+} 424.164$, Calc. 424.163 . (Found: $\mathrm{C}, 65.14 ; \mathrm{H}, 5.78 ; \mathrm{N}, 6.54$. Calc. for $\mathrm{C}_{23} \mathrm{H}_{24} \mathrm{~N}_{2} \mathrm{O}_{6}(424.46)$ : $\mathrm{C}, 65.08 ; \mathrm{H}, 5.70 ; \mathrm{N}, 6.60 \%$ ).

3- Carboxy - 1 - cyano - 2 - (3 - hydroxypropyl) benz[g]indoline - 3 acetic acid, dimethyl ester $8 \mathrm{c}$

To a soln of sodium carbonate $(2 \mathrm{~g})$ in $90 \mathrm{ml}$ of a $1: 1: 1$ mixture of $\mathrm{H}_{2} \mathrm{O}, \mathrm{MeOH}$ and THF $8 \mathrm{~b}(1.0 \mathrm{~g}, 2,4 \mathrm{mmol})$ was added. After stirring for $3.5 \mathrm{~h}$ at room temp the reaction was complete. Most of the $\mathrm{MeOH}$ and THF were removed under reduced pressure. The resulting residue was dissolved in $\mathrm{CHCl}_{3}$, washed with water and dried with $\mathrm{MgSO}_{4}$. The solvent was evaporated to give an oil which solidified upon the addition of a few drops of $\mathrm{Et}_{2} \mathrm{O}$. Purification by trituration with diisopropyl ether and recrystallization from $\mathrm{CHCl}_{3} /$ light petroleum (60/80) gave pure $8 \mathrm{c}$ in $72 \%$ yield. M.p. $126.5-128^{\circ}$; ${ }^{1} \mathrm{H}$ NMR: $88.5-8.3(\mathrm{~m}, 1 \mathrm{H}, \mathrm{Ar}), 87.9-7.3$ (m, 5H, Ar), 85.05 (dd, $J=5.5$ and $8 \mathrm{~Hz}, \mathrm{~N}-\mathrm{CH}-$ ), $83.8-3.5$ (m, $\left.2 \mathrm{H}, \mathrm{HO}-\mathrm{CH}_{2}-\right), \delta 3.74\left(\mathrm{~s}, 6 \mathrm{H}, \mathrm{OCH}_{3}\right), 83.58$ and $2.84(\mathrm{AB}-\mathrm{q}$, $\left.J=18 \mathrm{~Hz}, \mathrm{CH}_{2} \mathrm{E}\right), \delta 2.3-1.5\left(\mathrm{~m}, 4 \mathrm{H},-\mathrm{CH}_{2}-{ }^{13} \mathrm{C}\right.$ NMR: $\delta 172.0$ and $171.2(\mathrm{~s}, \mathrm{C}=0$ ), $\delta 135.6$ (s), 134.7 (s), 128.6 (d), 126.9 (d), $125.8(\mathrm{~d}), 125.4(\mathrm{~s}), 122.0(\mathrm{~s}), 121.2(\mathrm{~d})$ and 120.7 (d) (Ar), 8114.1

$(\mathrm{s}, \mathrm{C} \equiv \mathrm{N}), 870.8(\mathrm{~d}, \mathrm{~N}-\mathrm{CH}-), 861.8 \quad\left(\mathrm{t}, \mathrm{CH}_{2} \mathrm{OH}\right), 856.9$ [s, $\left.\mathrm{C}(\mathrm{E}) \mathrm{CH}_{2} \mathrm{E}\right], 853.2$ and $52.3\left(\mathrm{q}, \mathrm{OCH}_{3}\right), 836.2\left(\mathrm{t}, \mathrm{CH}_{2} \mathrm{E}\right), \delta 29.1$ and $26.8\left(\mathrm{t},-\mathrm{CH}_{2}\right)$. IR $(\mathrm{KBr}): 3480 \mathrm{~cm}^{-1}(\mathrm{OH}), 2222 \mathrm{~cm}^{-1}(\mathrm{C} \equiv \mathrm{N})$, $1729 \mathrm{~cm}^{-1}(C=0)$. MS: $M^{+} 382.153$, Calc. 382.153. (Found: $C$, $65.67 ; \mathrm{H}, 5.89 ; \mathrm{N}, 7.21$. Calc. for $\mathrm{C}_{21} \mathrm{H}_{22} \mathrm{~N}_{2} \mathrm{O}_{5}(382.42)$ : C, 65.96; $\mathrm{H}$, $5.80 ; \mathrm{N}, 7.33 \%)$

3- Carboxy - 1 - cyano - 2-(2 - formylethyl)benz[g]indoline - 3 acetic acid, dimethyl ester $8 d$

To a suspension of pyridinium chlorochromate $(0.27 \mathrm{~g}$, $1.3 \mathrm{mmol})$ in $3 \mathrm{ml} \mathrm{CH} \mathrm{Cl}_{2}$, a soln. of $8 \mathrm{c}(0.30 \mathrm{~g}, 0.8 \mathrm{mmol})$ in $3 \mathrm{ml}$ $\mathrm{CH}_{2} \mathrm{Cl}_{2}$ was rapidly added under $\mathrm{N}_{2}$ at room temp. After stirring for $3 \mathrm{~h}$ the black reaction mixture was passed through a short florisil column with $\mathrm{CHCl}_{3}$ : $\mathrm{EtOAc} 1: 1$ as the eluent. The solvents were evaporated in vacuo and the residue was treated with a small amount of diisopropyl ether to give a solid product 8d. Trituration with diisopropyl ether and recrystallization from $\mathrm{Et}_{2} \mathrm{O}$ afforded pure $8 \mathrm{~d}$ in $80 \%$ yield. M.p. $134-135^{\circ}$; ${ }^{\prime} \mathrm{H}$ NMR: $89.87(\mathrm{~s}, 1 \mathrm{H}, \mathrm{H}-\mathrm{C}=0), 88.4-8.2(\mathrm{~m}, 1 \mathrm{H}, \mathrm{Ar}), 87.9-7.3(\mathrm{~m}, 5 \mathrm{H}$, $\mathrm{Ar}$ ), 85.06 (dd, $J=6$ and $8 \mathrm{~Hz}, \mathrm{~N}-\mathrm{C} \mathrm{H}-$ ), 83.76 and 3.74 (s, $\left.\mathrm{OCH}_{3}\right), 83.64$ and $2.82\left(\mathrm{AB}-\mathrm{q}, J=18 \mathrm{~Hz}, \mathrm{CH}_{2} \mathrm{E}\right), 83.1-2.8(\mathrm{~m}$, $\left.2 \mathrm{H},-\mathrm{CH}_{2-}\right), \delta 2.1-1.8\left(\mathrm{~m}, 2 \mathrm{H},-\mathrm{CH}_{2}-\right) .{ }^{13} \mathrm{C} \mathrm{NMR}: \delta 199.5(\mathrm{~s}$, $\left.\mathrm{H}-\mathrm{C}^{\prime}=0\right), \delta 171.7$ and $171.0(\mathrm{~s}, \mathrm{C}=\mathrm{O}), \delta 135.3(\mathrm{~s}), 134.7(\mathrm{~s}), 128.6$ (d), 122.0 (d), 126.1 (d), 125.3 (s), 122.1 (s), 121.1 (d) and 120.6 (d) $(\mathrm{Ar}), 8113.9(\mathrm{~s}, \mathrm{C} \equiv \mathrm{N}), 870.5(\mathrm{~d}, \mathrm{~N}-\mathrm{C} H-), 857.1 \mathrm{~s},\left[\mathrm{C}\left(\mathrm{E}^{\mathrm{C}} \mathrm{CH}_{2} \mathrm{E}\right]\right.$, 853.3 and $52.3\left(\mathrm{q}, \mathrm{OCH}_{3}\right), 840.4\left(\mathrm{t}, \mathrm{H}_{2} \mathrm{C}-\mathrm{CH}=0\right), 836.2(\mathrm{t}$, $\left.\mathrm{CH}_{2} \mathrm{E}\right), \delta 22.8\left(\mathrm{t},-\mathrm{CH}_{2}-\right)$. IR $(\mathrm{KBr}): 2220 \mathrm{~cm}^{-1}(\mathrm{C} \equiv \mathrm{N}), 1735 \mathrm{~cm}^{-1}$ $\left(C=0\right.$, esters). MS: $M^{+} 380.137$, Calc. 380.137 . (Found: $C$, 66.10; $\mathrm{H}, 5.53 ; \mathrm{N}, 7.20$. Calc. for $\mathrm{C}_{21} \mathrm{H}_{20} \mathrm{~N}_{2} \mathrm{O}_{3}(380.405)$ : C, 66.31; $\mathrm{H}$, $5.30 ; \mathrm{N}, 7.36 \%)$

\section{7-Carboxy-7a,8,9,10-tetrahydro-4-(trifuoroacetyl)-7H-benzo[g]} pyrrolo[1,2-a]indole-7-acetic acid, dimethyl ester 11

A suspension of $6(0.50 \mathrm{~g}, 1.5 \mathrm{mmol})$ and $10 \mathrm{ml}$ trifluoroacetic anhydride was refluxed under $\mathrm{N}_{2}$ for $2 \mathrm{~h}$. After evaporation of most of the trifluoroacetic anhydride in vacuo, the residue, dissolved in $\mathrm{CHCl}_{3}$, was passed through a short column of silica gel. The $\mathrm{CHCl}_{3}$ was removed and the resulting yellow solid recrystallized from $\mathrm{Et}_{2} \mathrm{O} /$ light petroleum $(40 / 60)$ affording pure 11 in $78 \%$ yield. M.p. $152.5-153.5^{\circ}$; ${ }^{~ H}$ NMR: $\delta 9.26$ (dd, $J_{\text {ortho }}=$ $8 \mathrm{~Hz}, J_{\text {meta }}=1.5 \mathrm{~Hz}, 1 \mathrm{H}, \mathrm{Ar}$ ), $\delta 8.2-7.3(\mathrm{~m}, 4 \mathrm{H}, \mathrm{Ar}$ ), 85.10 (dd, $\left(\mathrm{m}, 1 \mathrm{H}, \mathrm{N}-\mathrm{CH}_{2}\right), 83.75$ and $3.73\left(\mathrm{~s}, \mathrm{OCH}_{3}\right), 83.66$ and 2.85 
(AB-q, $\left.\mathrm{J}=18 \mathrm{~Hz}, \mathrm{CH}_{2} \mathrm{E}\right), 82.4-1.7(\mathrm{~m}, 3 \mathrm{H}), 81.7-1.0(\mathrm{~m}, \mathrm{lH}) .{ }^{13} \mathrm{C}$ NMR: $\delta 178.7\left(\mathrm{q}, \mathrm{O}=\mathrm{C}-\mathrm{CF}_{3}\right), \delta 172.8$ and $171.4(\mathrm{~s}, \mathrm{C}=0), \delta 156.1$ (s), 135.4 (s), 130.2 (d), 126.6 (d), 125.2 (d), 124.7 (d), 121.7 (s), 121.5 (s) and $115.4(\mathrm{~s})(\mathrm{Ar}), \delta 117.3\left(\mathrm{q}, J=288 \mathrm{~Hz}, \mathrm{CF}_{3}\right), \delta 73.1$ (d, $\mathrm{N}-\mathrm{CH}-), \delta 52.9\left[\mathrm{~s}, \mathrm{C}(\mathrm{E}) \mathrm{CH}_{2} \mathrm{E}\right], \delta 53.0$ and $\$ 2.1\left(\mathrm{q}, \mathrm{OCH}_{3}\right), \delta 51.6$ (t, N-CH $\left.{ }_{2}\right), 839.3\left(\mathrm{t}, \mathrm{CH}_{2} \mathrm{E}\right), \delta 26.4\left(\mathrm{~m}, 2 \mathrm{x}-\mathrm{CH}_{2}-\right)$. IR (KBr): 1748 and $1730(\mathrm{sh}) \mathrm{cm}^{-1}\left(\mathrm{C}=0\right.$, esters), $1662 \mathrm{~cm}^{-1}\left(\mathrm{O}=\mathrm{C}-\mathrm{CF}_{3}\right)$. MS: $\mathrm{M}^{+}$435.128, Calc. 435.129. (Found: C, 60.73; H, 4.61; N, 3.18. Calc. for $\mathrm{C}_{22} \mathrm{H}_{20} \mathrm{~F}_{3} \mathrm{NO}_{5}(435.40)$ ): $\mathrm{C}, 60.69 ; \mathrm{H}, 4.63 ; \mathrm{N}, 3.22 \%$ ).

9, 10-Dihydro-7-methyl-8H-benzo[g]pyrrolo[1,2-a]indole 13.

To a soln of $6(2.04 \mathrm{~g}, 6.0 \mathrm{mmol})$ in $12 \mathrm{ml}$ quinoline was added dry acetic acid $(6.12 \mathrm{ml}, 108 \mathrm{mmol})$ under a slow stream of $\mathrm{N}_{2}$. The reaction mixture was heated at $200^{\circ}$ for $40 \mathrm{~h}$. Most of the quinoline was removed under reduced pressure. The residue, dissolved in $\mathrm{CH}_{2} \mathrm{Cl}_{2}$, was passed through a short column of florisil. After removal of the solvent the resulting solid was purified by trituration with light petroleum (60/80) affording 13 in $36 \%$ yield. A sample was recrystallized from ethanol M.p. 151.0 $152.5^{\circ}$; ${ }^{1} \mathrm{H}$ NMR: $88.3-8.15(\mathrm{~m}, 1 \mathrm{H}, \mathrm{Ar}), 8.0-7.8(\mathrm{~m}, 1 \mathrm{H}, \mathrm{Ar})$ 7.7-7.25 (m, 4H, Ar), $4.50\left(\mathrm{t}, \mathrm{J}=7 \mathrm{~Hz}, \mathrm{~N}-\mathrm{CH}_{2}-\right), 3.1-2.5(\mathrm{~m}, 4 \mathrm{H}$ $-\mathrm{CH}_{2}-$ ), $2.32\left(\mathrm{~s}, \mathrm{CH}_{3}\right) .{ }^{13} \mathrm{C}$ NMR: $\delta 139.8$ (s), 129.9 (s), 128.6 (d), 124.7 (d), 122.4 (d), 120.0 (d), 119.1 (d), 118.9 (d), 102.3 (s) (sp ${ }^{2}$-carbon atoms), $\delta 47.1\left(\mathrm{t}, \mathrm{N}-\mathrm{CH}_{2}\right.$ ),$\delta 28.1$ and $22.4\left(\mathrm{t},-\mathrm{CH}_{2}\right.$ ) $\delta 9.0\left(\mathrm{q}, \mathrm{CH}_{3}\right.$ ). MS: $\mathrm{M}^{+} 221.120$, Calc. 221.120. (Found: $\mathrm{C}, 86.67 ; \mathrm{H}$, 6.92; N, 6.26. Calc. for $\mathrm{C}_{16} \mathrm{H}_{15} \mathrm{~N}(221.30): \mathrm{C}, 86.84 ; \mathrm{H}, 6.83 ; \mathrm{N}$, 6.33\%).

Acknowledgement-We are grateful for the financial support of this work by the "Koningin Wilhelmina Fonds". The authors wish to express their gratitude to Miss J.M. Visser and Miss J.L.M. Vrielink for recording the NMR spectra and to Mr. T.W. Stevens for recording the mass spectra.

\section{REFERENCES}

${ }^{1}$ D. N. Reinhoudt, J. Geevers, W. P. Trompenaars, S. Harkema and G. J. van Hummel, J. Org. Chem. 46, 424 (1981).
${ }^{2}$ J. Geevers, G. W. Visser, W. P. Trompenaars, D. N. Reinhoudt, Recl. Trav. Chim. Pays-Bas 98, 251 (1979).

${ }^{3}$ W. Verboom, G. W. Visser, W. P. Trompenaars, D. N. Reinhoudt, S. Harkema and G. J. van Hummel, Tetrahedron 37, 3525 (1981). ${ }^{4}$ For a review see: W. Szybalski and V. N. Iyer, Antibiotics I (Edited by D. Gottlieb and P. D. Shaw), p. 211. Springer-Verlag, Berlin (1967).

${ }^{5}$ For a review see: K. Takahashi and T. Kametani, Heterocycles 13, 411 (1979).

${ }^{6}$ F. Nakatsubo, T. Fukuyama, A. J. Cocuzza and Y. Kishi, J. Am. Chem. Soc. 99, 8115 (1977); T. Fukuyama, F. Nakatsubo, A. J. Cocuzza and Y. Kishi, Tetrahedron Letters 4295 (1977); Y. Kishi, J. Nat. Prod. 42, 549 (1979).

${ }^{7}$ T. Kametani, K. Takahashi, M. Ihara and K. Fukumoto, J. Chem. Soc. Perkin I 1847 (1979).

${ }^{B}$ H. A. Hageman, Org. Reactions 7, 198 (1953).

9J. D. Albright and L. Goldman, J. Am. Chem. Soc, 91, 4317 (1969). ${ }^{10}$ H. Rönsch, J. prakt. Chem. 314, 382 (1972).

${ }^{11}$ A. G. Cook. Enamines, Synthesis, Structure and Reactions (Edited by A. G. Cook), p. 155 and 400-401. Marcel Dekker, New York (1969).

${ }^{12} \mathrm{D}$. N. Reinhoudt, W. P. Trompenaars and J. Geevers, Synthesis 368 (1978)

${ }^{13}$ C. L. Liotta, H. P. Harris, M. McDermott, T. Gonzalez and K. Smith, Tetrahedron Letters 2417 (1974).

${ }^{14}$ E. J. Corey and J. W. Suggs, Jbid 2647 (1975).

${ }^{15}$ For several examples see: R. E. A. Dear, Intra-Sci. Chem. Rep. 5 , 37 (1971); R. K. Mackie, S.Mhatre and J. M. Tedder, J. Fluorine Chem. 10, 437 (1977); L. J. Mathias and C. G. Overberger, J. Org. Chem. 45, 1701 (1980) and references cited therein.

${ }^{16} \mathrm{G}$. Aranda and M. Fétizon, Synthesis 330 (1975).

${ }^{17}$ A. S. Bailey, P. W. Scott and M. H. Vandrevala, J. Chem. Soc. Perkin I 97 (1980).

${ }^{18}$ P. A. Bartlett and W. S. Johnson, Tetrahedron Letters 4459 (1970). 